\title{
Shade Tolerance of Grass and Legume Germ- plasm for Use in the Southern Forest Range
}

\author{
VANCE H. WATSON, CHARLES HAGEDORN, WILLIAM E. KNIGHT, AND HENRY A. PEARSON
}

\begin{abstract}
A series of experiments was conducted during 1978, 1979, and 1980 to screen selected cultivars of grasses and legumes for their adaptation and performance under a multiple harvest system in a shaded environment. Acceptable stands of all species except Uniola sessilfflora Michx. were obtained under each shade treatment. The most shade tolerant species were 'Nangeela' subclover (Trifolium subterraneum L.), ryegrass (Lolium multiflorium Lam.), Persian clover (Trifolium resupinatum L.) and crimson clover (Trifolium incarnatum L.). Shade reduced the height of species with an upright growth habit while decumbent type species (subclover) showed less reduction. Nitrogen content was not affected by shade while potassium and phosphorus levels increased for all species under $50 \%$ shade. In separate field experiments the yield, stand density, and persistence of sericen lespedeza \{Lespedeza cuneata (Dumont) G. Don\} decreased with increasing shade although crude protein content was not affected. Cultivars of 4 species, ('Mt. Barker' subclover, 'Tibbee' crimson clover, 'Kentucky 31' tall fescue (Festuca arundinacea Schreb.), and 'Gulf' ryegrass), had acceptable stands and yields under $50 \%$ shade in a multiple harvest regime. These results demonstrate that several forage species are sufficiently shade tolerant to warrant consideration for use in forested environments.
\end{abstract}

It has been demonstrated that potential forage biomass production is higher in the South than in any other range area of comparable size in the United States (Grelen 1978). However, native range production is declining rapidly due to accelerated pine regeneration and the establishment of fast-growing slash (Pinus elliottii Engelm.) and loblolly pine ( $P$. taeda L.), which results in drastically reduced herbage production within a few years. Grelen stated that operational scale multiple-use research is badly needed to evaluate compatability of tree production, wild life, livestock, and other resources.

One promising possibility for improving the southern forest range is the introduction of shade tolerant forages. Such germplasm could provide better quality forage over an extended period for both wildlife and livestock, could serve as a groundcover to reduce erosion during the winter, and could contribute to soil organic matter levels and add nitrogen in the case of legumes.

This study reports an evaluation of the effects of shade on morphological and physiological characteristics of selected forage species.

\footnotetext{
Authors are professor and associate professor of agronomy, P.O. Box 5248, Department of Agronomy: research agronomist, Crop Science Research Lab. USDA-ARS, Mississippi Agr. and Forestry Exp. Sta., Mississippi State 39762; and project leader, USDA Southern Forest Exp. Sta. Pineville, La. 71360.

This research is a contribution from the Dep. of Agronomy, Mississippi State Univ., and the Mississippi Agr. and Forestry Exp. Sta. Approved by the Director as Technical Paper No. 5432. The research was conducted under Cooperative Agreement No. 19-299 between the U.S. Forest Service, Southern Forest Exp. Sta., Range Management Research and the Mississippi Agr. and Forestry Exp. Sta. This project is endorsed by the U.S. Man and Biosphere Program (MAB-3) contributing to grazing land management objectives.

Manuscript received March 30, 1983.
}

\section{Methods}

\section{Experiment 1A}

Twenty species and/or cultivars of cool-season grasses and legumes were planted on a prepared seedbed on October 20,1978, at Mississippi State, Miss. (Table 1). All species were planted in

Table 1. Species and varieties of grass and legume germplasm subjected to shade management at Mississippi State University, 1978.

\begin{tabular}{|c|c|c|}
\hline Species & Variety & Common name \\
\hline Trifolium subterraneum $\mathbf{L}$. & $\begin{array}{l}\text { Nangeela } \\
\text { Woogenellup } \\
\text { Daliak } \\
\text { Geraldton } \\
\text { Miss. Ecotype } \\
\text { Tallarook } \\
\text { Mt. Barker } \\
\text { Dwalganup }\end{array}$ & Sub Clover \\
\hline Trifolium vesiculosum Savii. & $\begin{array}{l}\text { Amclo } \\
\text { Yuchi } \\
\text { Meechee }\end{array}$ & Arrowleaf Clover \\
\hline $\begin{array}{l}\text { Trifolium nigrescens } \mathrm{L} . \\
\text { Trifolium resupinatum } \mathrm{L} . \\
\text { Trifolium alexandrinum } \mathrm{L} . \\
\text { Trifolium incarnatum } \mathrm{L} . \\
\text { Festuca arundinacea Schreb. } \\
\text { Lolium multiflorium Lam. } \\
\text { Uniola sessiliflora Michx. } \\
\text { Vicia villosa Roth. }\end{array}$ & $\begin{array}{l}\text { Chief, Tibbee } \\
\text { Kentucky } 31 \\
\text { Marshall } \\
-\end{array}$ & $\begin{array}{l}\text { Ball Clover } \\
\text { Persian Clover } \\
\text { Berseem Clover } \\
\text { Crimson Clover } \\
\text { Tall Fescue } \\
\text { Ryegrass } \\
\text { Uniola (Broadleaf) } \\
\text { Hairy Vetch }\end{array}$ \\
\hline
\end{tabular}

Where no cultivar is designated the seed was purchased as a common brand (non-varietal)

single row plots $30 \mathrm{~cm}$ wide $\times 2 \mathrm{~m}$ long. Immediately after planting, artificial shade chambers were placed over the planted areas. Shade chambers were constructed from lumite vinyl shade cloth designed to provide 50 and $25 \%$ of natural illumination. The shade cloth was mounted on $2 \times 5$ meter metal frames with legs to maintain them $30 \mathrm{~cm}$ above the soil surface. Soil pH was 6.7 and fertility was maintained at adequate levels for all species.

The experimental design was a split-plot with level of shading as whole plots and species and/or cultivars as subplots. There were 4 replications. Data were collected on each of the species after seedling emergence for stand quality parameters.

All plots were harvested May 14, 1979. Parameters measured were dry matter yield, percent dry matter, height, root and nodule weights, and mineral composition for nitrogen, potassium, phosphorus, sulfur, magnesium, calcium, iron, aluminum, manganese, and boron. Dry matter yields were determined by harvesting the entire plot with a hand sickle to a stubble height of $2.54 \mathrm{~cm}$. The forage was weighed and dried in a forced draft oven at $60^{\circ} \mathrm{C}$ for 36 
Table 2. Seedling counts, relative yield, plant height, and percent dry matter of 20 species grown under three levels of shade in 1979.

\begin{tabular}{|c|c|c|c|c|c|c|c|c|c|c|c|}
\hline \multirow[b]{2}{*}{ Species } & \multicolumn{11}{|c|}{ Level of Shade (\%) } \\
\hline & 0 & 50 & 75 & 50 & 75 & 0 & 50 & 75 & 0 & 50 & 75 \\
\hline & \multicolumn{3}{|c|}{ Seedlings per $30.5 \mathrm{~cm}$ of row } & \multicolumn{2}{|c|}{$\%$ of yield in full sun } & \multicolumn{3}{|c|}{ Plant height $\mathrm{cm}$} & \multicolumn{3}{|c|}{ Dry matter \% } \\
\hline Nangella Subclover & 46 & 49 & 47 & 92 & 49 & 12 & 13 & 9 & 28 & 23 & 25 \\
\hline Woogenellup Subclover & 30 & 33 & 30 & 59 & 26 & 14 & 15 & 11 & 29 & 25 & 26 \\
\hline Miss. Ecotype Subclover & 34 & 34 & 35 & 55 & 32 & 9 & 12 & 10 & 24 & 21 & 26 \\
\hline Tallarook Subclover & 37 & 40 & 42 & 48 & 26 & 14 & 14 & 10 & 25 & 22 & 25 \\
\hline Mt. Barker Subclover & 41 & 44 & 34 & 37 & 24 & 15 & 15 & 9 & 26 & 22 & 24 \\
\hline Dwalganup Subclover & 23 & 32 & 25 & 65 & 24 & 12 & 11 & 9 & 29 & 24 & 29 \\
\hline Amclo Arrowleaf Clover & 11 & 9 & 13 & 34 & 27 & 59 & 30 & 23 & 24 & 18 & 21 \\
\hline Yuchi Arrowleaf Clover & 4 & 8 & 6 & 57 & 49 & 51 & 32 & 30 & 22 & 18 & 18 \\
\hline Meechee Arrowleaf Clover & 2 & 4 & 10 & 39 & 23 & 47 & 29 & 22 & 21 & 16 & 17 \\
\hline Persian Clover & 15 & 16 & 15 & 58 & 36 & 25 & 17 & 12 & 25 & 18 & 20 \\
\hline Berseem Clover & 8 & 23 & 12 & 88 & 56 & 39 & 31 & 19 & 24 & 17 & 17 \\
\hline Chief Crimson Clover & 87 & 38 & 35 & 57 & 31 & 43 & 26 & 22 & 34 & 26 & 24 \\
\hline Tibbee Crimson Clover & 28 & 40 & 31 & 62 & 34 & 44 & 25 & 18 & 47 & 23 & 29 \\
\hline Ky 31 Tall Fescue & 18 & 16 & 18 & 39 & 29 & 13 & 24 & 21 & 35 & 29 & 30 \\
\hline Marshall Ryegrass & 60 & 54 & 60 & 51 & 28 & 72 & 38 & 31 & 23 & 23 & \\
\hline Uniola & 0 & 0 & 0 & - & - & 3 & 6 & $4^{2}$ & - & - & - \\
\hline Hairy Vetch & 21 & 18 & 18 & 33 & 22 & 38 & 21 & 15 & 17 & 17 & 18 \\
\hline $\operatorname{LSD}_{A}(.05)^{2}$ & 1 & 1 & 1 & 5 & 5 & 2 & 4 & 4 & & & \\
\hline $\operatorname{LSD}_{\mathrm{B}}(.05)$ & 1 & 1 & 0 & 2 & 3 & 2 & 2 & 2 & & & \\
\hline $\mathrm{CV}_{\mathrm{A}}(\%)$ & 6 & 13 & 16 & 12 & 13 & 12 & 15 & 17 & & & \\
\hline $\mathrm{CV}_{\mathrm{B}}(\%)$ & 5 & 6 & 10 & 19 & 11 & 11 & 17 & 18 & & & \\
\hline
\end{tabular}

IPlanted on $10 / 20 / 78$ and counted on $1 / 20 / 79$

${ }^{2}$ "A" refers to differences among cultivars within a shade level while "B" refers to differences across shade levels within a cultivar.

hours. The dried forage was ground in a Wiley mill fitted with a 1-mm screen. Samples were analyzed for mineral composition by the use of spectrophotometry (Carlisle 1978).

\section{Experiment 1B}

A 1-year-old stand of 'Serala' sericea lespedeza \{Lespedeza cuneata (Dumont) G. Don.\} located in Lauderdale County, Miss., was subjected to 3 levels of shade and harvested twice in 1979 and twice in 1980.
The experimental design was a randomized complete block with 3 replications and soil $\mathrm{pH}$ and fertility were maintained at adequate levels. Plot size was $3.81 \times 4.21 \mathrm{~m}$. Parameters measured were dry matter yield, stems per crown, estimated forage quality, and total available carbohydrates. Dry matter yields were determined by harvesting the plots with a sickle mower to a height of $2.54 \mathrm{~cm}$. The forage was weighed and dried in a forced draft oven for 36 hours at $60^{\circ} \mathrm{C}$. The dried forage was ground in a Wiley mill fitted with a $1-\mathrm{mm}$ screen and chemical analyses were run on the ground samples. Crude protein was determined from the Kjeldahl procedure

Table 3. Average nitrogen, potassium, and phosphorus content of grass and legume species and cultivars grown under three levels of shade in 1979.

\begin{tabular}{|c|c|c|c|c|c|c|c|c|c|}
\hline \multirow[b]{2}{*}{ Variety } & \multicolumn{9}{|c|}{ Level of shade (\%) } \\
\hline & $\mathbf{0}$ & 50 & 75 & 0 & 50 & 75 & 0 & 50 & 75 \\
\hline & \multicolumn{3}{|c|}{ Total nitrogen (\%) } & \multicolumn{3}{|c|}{ Potassium (\%) } & \multicolumn{3}{|c|}{ Phosphorus (\%) } \\
\hline Nangeela S.C. & 20 & 2.3 & 2.3 & 1.2 & 1.5 & 2.0 & .18 & .22 & .20 \\
\hline Woogenellup S.C. & 1.8 & 1.9 & 2.2 & 0.9 & 1.2 & 1.6 & .14 & .22 & .20 \\
\hline Miss. Ecotype S.C. & 2.0 & 2.4 & 2.4 & 1.2 & 1.5 & 1.7 & .17 & .26 & .22 \\
\hline Tallarook S.C. & 2.0 & 2.4 & 2.4 & 1.2 & 1.6 & 1.6 & .16 & .29 & .20 \\
\hline Mt. Barker S.C. & 1.7 & 2.3 & 2.6 & 1.3 & 1.4 & 1.6 & .13 & .24 & .24 \\
\hline Dwalganup S.C. & 1.4 & 2.2 & 2.0 & 0.9 & 1.5 & 1.5 & .12 & .25 & .23 \\
\hline Amclo Ar. C. & 1.9 & 2.3 & 2.3 & 1.2 & 1.9 & 2.2 & .16 & .27 & .27 \\
\hline Yuchi Ar. C. & 1.8 & 2.0 & 2.4 & 1.3 & 2.0 & 2.1 & .14 & .23 & .24 \\
\hline Meeche Ar. C. & 2.1 & 2.7 & 2.3 & 1.5 & 2.4 & 2.0 & .16 & .30 & .24 \\
\hline Persian Clover & 2.1 & 2.2 & 2.0 & 1.3 & 1.5 & 1.6 & .19 & .23 & .21 \\
\hline Berseem Clover & 1.7 & 2.3 & 2.3 & 1.1 & 2.0 & 1.8 & .12 & .23 & .27 \\
\hline Chief C.C. & 2.0 & 2.0 & 2.0 & 1.1 & 1.5 & 1.7 & .15 & .21 & .18 \\
\hline Tibbee C.C. & 1.4 & 1.7 & 1.8 & 1.0 & 1.5 & 2.0 & .15 & .19 & .20 \\
\hline K 31 Tall Fescue & 1.2 & 1.4 & 1.0 & 2.1 & 2.5 & 1.8 & .19 & .28 & .22 \\
\hline Marshall Ryegrass & 0.8 & 1.1 & 1.1 & 1.6 & 2.1 & 2.7 & .16 & .25 & .27 \\
\hline Hairy Vetch & 3.4 & 3.0 & 2.8 & 2.3 & 2.9 & 2.9 & .34 & .36 & .36 \\
\hline $\operatorname{LSD}_{A}(0.5)^{2}$ & 1.8 & 2.0 & 2.1 & 2.3 & 4.0 & 5.2 & 1.9 & 2.3 & 3.6 \\
\hline $\operatorname{LSD}_{\mathrm{B}}(0.5)$ & 1.2 & 1.3 & 1.4 & 3.7 & 4.1 & 5.8 & 1.8 & 2.2 & 3.8 \\
\hline$C V_{A}(\%)$ & 9.1 & 9.4 & 10.7 & 8.6 & 9.3 & 12.7 & 7.4 & 9.1 & 10.3 \\
\hline$C V_{B}(\%)$ & 9.1 & 9.9 & 11.4 & 9.2 & 10.9 & 14.6 & 8.5 & 10.3 & 12.0 \\
\hline
\end{tabular}

'S.C. = Subterranean Clover, Ar.C. $=$ Arrowleaf Clover, C.C. $=$ Crimson Clover.

${ }_{2 "} \mathrm{~A}$ " refers to differences among cultivars within a shade level while " $\mathrm{B}$ " refers to diffrences across shade levels within a cultivar. 
for total nitrogen, digestibility according to procedures of Van Soest (USDA Agr. Handbook 379) and total available carbohydrates after Weinmann (1947).

\section{Experiment 2}

Based on the results obtained in Experiment 1A, 4 species ('Mt. Barker' subterranean clover, 'Tibbee' crimson clover, 'Kentucky 31' tall fescue, and 'Gulf' ryegrass) were grown under 3 levels of shade and a multiple harvest schedule in 1979-80. Experimental design was a split plot with 4 replications as in Experiment $1 \mathrm{~A}$ and soil $\mathrm{pH}$ and fertility were adequate for all species. Plots. were planted on a prepared seedbed on September 20, 1979, at Mississippi State, Miss. Forage was harvested February 20, April 16, and May 18, 1980. The specific cultivars were chosen because of the availability of seed from commercial sources.

\section{Results}

\section{Experiment 1A:}

Acceptable stands of all species except Uniola were obtained (Table 2). In general, level of shade had little effect on the number of seedlings that germinated. Exceptions were 'Yuchi' and 'Meechee' arrowleaf clover and berseem clover, which had more seedlings present as level of shade increased. In contrast, numbers of seedlings of 'Geraldton' subclover decreased as shade increased. Ball clover did not germinate adequately under any treatment.

Moderate to heavy cold damage was recorded on some seedlings due to the widely fluctuating environmental conditions that were prevalent in Mississippi during the course of the observations. There was a trend for some species such as subterranean clover and hairy vetch to have less apparent cold damage as level of shade increased (data not shown).

Dry matter yields varied considerably among species and shade levels (Table 2). In general, yields across shade levels were highest for ryegrass followed by the subterranean and crimson clovers. Most yields decreased by $40 \%$ or more under $50 \%$ shade and by $75 \%$ or more under $75 \%$ shade. Exceptions were "Nangeela' subclover and Persian clover, where production was decreased 8 and $12 \%$, respectively, by $50 \%$ shade.

In contrast, root yields and the percent of root weight represented by nodules were not affected by shade (data not shown). Root weights ranged from 1.9 to $2.4 \mathrm{gm}$ dry matter per plant and nodules made up 12 to $15 \%$ of the root weight.

There were wide variations in height among species, and shade generally reduced the height of the upright type of species (Table 2). Decumbent type species such as the subclovers showed less variation in height among the levels of shade. There was a trend for percent dry matter to be lower in all species as level of shade increased. Plant maturity was delayed 5 to 10 days by shade.

Total nitrogen content was not affected by shade, but values obtained for the legumes were higher than for the grasses (Table 3). In contrast, potassium content of the grasses was generally higher than for the legumes, and there was a trend for potassium levels of all species to increase as level of shade increased. Phosphorus content increased in all species grown under $50 \%$ shade, but values did not change as shade was increased to $75 \%$. There were no trends related to species or shade for sulfur, magnesium, calcium, manganese, or boron content. No definite trends were observed in iron and aluminum content.

\section{Experiment 1B}

Dry matter yield of sericea lespedeza (Table 4) decreased significantly as the level of shade was increased, and the response was magnified as the growing season progressed. Yields under $75 \%$ shade were only $50 \%$ of those in full sun by the second harvest for both years. Plants grown under shade were also significantly shorter at the second harvest. However, plants growing in $50 \%$ shade persisted and produced satisfactory yields through both years of the experiment.

Numbers of stems per crown was decreased significantly in the second growth (regrowth) forage by shade (Table 4). Percent leaves was also decreased in the first harvest as level of shade increased, but not in the regrowth.

Neither crude protein content nor digestibility was affected by shade for either harvest. Crude protein content of sericea $(16 \%)$ was high enough throughout the season to meet the requirements of ruminant animals.

Average total available carbohydrates (TAC) in the root systems of sericea averaged 31,27 , and $10 \%$ for 0,50 , and $75 \%$ shade, respectively, suggesting that shade should not exceed $50 \%$ for good stand persistence.

\section{Experiment 2}

Under a multiple harvest regime, dry matter yields decreased for each species as level of shade increased (Table 5). However, performance of the 4 species was satisfactory under $50 \%$ shade, acceptable yields were produced, and all of the species yielded sufficient seed to re-establish themselves the next growing season. Establishment of a good stand the first year and regulation of late spring grazing to permit seed production are critical to continued persistence.

\section{Discussion}

Within the southeastern United States, there have been a number of sporadic reports on the use of traditionally agronomic forages in forestry situations. None have started with an evaluation of shade tolerance and most have emphasized the potential benefits of increased tree production through associations with legumes.

The present investigation emphasized legumes and cool season forages because it is during the winter months that adequate browse is least available in southern pine forests. Subclover has been used extensively in forest environments in Australia because of its shade tolerance, persistence under unfavorable conditions, and forage quality (Anderson and Batini 1979). Other research

Table 4. Dry matter yields, height, stems per crown, and percent leaves for Sericea lespedeza grown under three levels of shade. Lauderdale, Co., MS, 1979-1980.

\begin{tabular}{|c|c|c|c|c|c|c|c|c|c|c|c|c|}
\hline \multirow[b]{3}{*}{$\%$ Shade } & \multicolumn{6}{|c|}{ Dry matter yield } & \multicolumn{6}{|c|}{1979} \\
\hline & \multicolumn{3}{|c|}{1979} & \multicolumn{3}{|c|}{1980} & \multicolumn{2}{|c|}{ Height-cm } & \multicolumn{2}{|c|}{ Stem/crown } & \multicolumn{2}{|c|}{$\%$ Leaves } \\
\hline & $6 / 4$ & $8 / 3$ & Total & $6 / 6$ & $8 / 7$ & Total & $6 / 4$ & $8 / 3$ & $6 / 4$ & $8 / 3$ & $6 / 4$ & $8 / 3$ \\
\hline $\begin{array}{r}0 \\
50 \\
75\end{array}$ & $\begin{array}{l}4900 \\
4160 \\
3830\end{array}$ & $\begin{array}{l}3350 \\
2546 \\
1740\end{array}$ & $\begin{array}{l}8250 \\
6706 \\
5570\end{array}$ & $\begin{array}{l}4820 \\
3220 \\
1410\end{array}$ & $\begin{array}{r}2670 \\
1926 \\
620\end{array}$ & $\begin{array}{l}7490 \\
5146 \\
2030\end{array}$ & $\begin{array}{l}75 \\
78 \\
76\end{array}$ & $\begin{array}{l}65 \\
53 \\
52\end{array}$ & $\begin{array}{r}10.4 \\
10.2 \\
8.9\end{array}$ & $\begin{array}{r}11.7 \\
8.6 \\
9.1\end{array}$ & $\begin{array}{l}63.4 \\
56.6 \\
59.5\end{array}$ & $\begin{array}{l}63.0 \\
61.0 \\
61.3\end{array}$ \\
\hline $\begin{array}{l}\operatorname{LSD}(.05) \\
\mathrm{CV}(\%)\end{array}$ & $\begin{array}{c}760 \\
9.2\end{array}$ & $\begin{array}{l}472 \\
10.5\end{array}$ & $\begin{array}{r}1100 \\
9.8\end{array}$ & $\begin{array}{l}818 \\
9.7\end{array}$ & $\begin{array}{l}592 \\
1.6\end{array}$ & $\begin{array}{r}1215 \\
8.4\end{array}$ & $\begin{array}{l}1.6 \\
9.5\end{array}$ & $\begin{array}{l}0.9 \\
4.0\end{array}$ & $\begin{array}{r}\text { n.s. } \\
15.4\end{array}$ & $\begin{array}{l}1.0 \\
6.9\end{array}$ & $\begin{array}{r}2.5 \\
10.6\end{array}$ & $\begin{array}{l}\text { n.s. } \\
5.7\end{array}$ \\
\hline
\end{tabular}


Table 5. Dry matter yield of ryegrass, tall fescue, subterranean clover, and crimson clover under three levels of shade at Mississippi State, MS, $1979-80$.

\begin{tabular}{|c|c|c|c|c|}
\hline & \multicolumn{4}{|c|}{ D.M. Yield-Lbs./A. } \\
\hline & $2 / 80$ & $4 / 80$ & $5 / 80$ & Total \\
\hline $\begin{array}{r}0 \\
50 \\
75\end{array}$ & $\begin{array}{l}786 \\
620 \\
600\end{array}$ & $\begin{array}{l}5974 \\
4500 \\
2076\end{array}$ & $\begin{array}{l}\text { Ryegras } \\
1385 \\
1158 \\
1079\end{array}$ & $\begin{array}{l}8145 a^{1} \\
6278 b \\
3755 c\end{array}$ \\
\hline $\begin{array}{r}0 \\
50 \\
75\end{array}$ & $\begin{array}{l}742 \\
720 \\
676\end{array}$ & $\begin{array}{l}\text { 'Kent } \\
3190 \\
2415 \\
2292\end{array}$ & $\begin{array}{c}\text { 1' Tall F } \\
1299 \\
765 \\
627\end{array}$ & $\begin{array}{ll}5231 & a \\
3900 & b \\
3595 & b\end{array}$ \\
\hline $\begin{array}{r}0 \\
50 \\
75\end{array}$ & $\begin{array}{l}620 \\
606 \\
537\end{array}$ & $\begin{array}{l}\text { 'Mt. } \\
3011 \\
1875 \\
1664\end{array}$ & $\begin{array}{l}\text { r' Subcl } \\
1158 \\
1475 \\
697\end{array}$ & $\begin{array}{l}4789 \mathrm{a} \\
3956 \mathrm{~b} \\
2898 \mathrm{c}\end{array}$ \\
\hline $\begin{array}{l}0 \\
50 \\
75 \\
\text { LSD }(.05) \\
\text { CV }(\%)\end{array}$ & $\begin{array}{l}715 \\
622 \\
543 \\
\text { N.S. } \\
15.3\end{array}$ & $\begin{array}{l}\text { 'Tibb } \\
3174 \\
1695 \\
1523 \\
1173 \\
11.3\end{array}$ & $\begin{array}{c}\text { Imson C } \\
983 \\
1100 \\
521 \\
649 \\
13.6\end{array}$ & $\begin{array}{c}4872 \text { a } \\
3417 \text { b } \\
2587 \text { c } \\
896 \\
11.1\end{array}$ \\
\hline
\end{tabular}

'Letters indicate significant differences at the $5 \%$ level according to Duncan's Multiple-Range Test. results confirm that some cultivars of subclover would be excellent choices for use in forested settings in the South (Haines et al., White, and Sawyer 1978) as well as 'Chief' and 'Tibbee' crimsom clover, 'Marshall' ryegrass and 'Kentucky 31 ' tall fescue. Further research should examine the productivity and persistence of such shade tolerant forages under more naturalized forested settings.

\section{Literature Cited}

Anderson, G.W., and F.E. Batini, 1979. Clover and crop production under 13 to 15-year-old Pinus radiata. Aust. J. Exp. Agr. Anim. Husb. 19:362-368.

Anonymous, Rural Research, 1978. CSIRO Quarterly. 99:4-9.

Carlisle, R.J., V.H. Watson, and A.W. Cole. 1978. Canopy and chemistry of pasture weeds. Weed Sci. 28:139-142.

Grelen, H.E. 1978. Forest grazing in the South. J. Range Manage. 31:244-250.

Haines, S.G. 1978. Potential uses of nitrogen-fixing plants in forestry, p. 1-19. In: S.G. Haines (ed.), Nitrogen fixation in southern forestry. International Paper, Co., Bainbridge, Ga.

Haines, S.G., L.W Haines, and G. White. 1978. Leguminous plants increase sycamore growth in northern Alabama. Soil Sci. Soc. Amer. J. 42:130-132.

Sawyer, G.E.J. 1978. Evaluation of four clovers on a forest soil. p. 108-111. In: S.G. Haines (ed.) Nitrogen fixation in southern forestry. International Paper Co., Bainbridge, Ga.

Weinmann, H. 1947. Determination of total available carbohydrates in plants. Plant Physiol. 22:279-290.

\section{Membership in the Society for Range Management. . .}

is open to those engaged in or interested in the study. management, or use of range ecosystems and the intelligent use of all range resources

includes research scientists, ranchers, govemmental ogency administrators and technical personnel. teachers, students, and people from the business community

provides members with two publications - one oriented to research (Journal of Range Management) and the other oriented to practical resource management (Rangelands) offers opportunities for face-to-face exchange of ideas at local, national, and intemational meetings of the Society.

Dues vary according to type of membership and geographical section. For application forms and additional information, contact the:

Society for Range Management

2760 West Fifth Avenue

Denver. Colorado 80204

(303) 571-0174 